DOI: https://doi.org/10.18371/fp.2(34).2019.183589

УДК 65.011 .1

\title{
БЕНЧМАРКІНГ ЯК СПОСІБ УНИКНЕННЯ КРИЗОВИХ ЯВИЩ НА ПІДПРИєМСТВІ
}

\section{ГОРДЕЙ Оксана Дмитрівна}

доктор економічних наук, професор, професор кафедри фінансів імені Л.Л. Тарангул

Університету державної фіскальної служби Украӥни

ORCIDID: http://orcid.org/0000-0001-6938-0548

e-mail:ohordei@gmail.com

\section{ЖОЛОБ Анастасія Олександрівна}

студентка Університету державної фіскальної служби України e-mail:anastasiiazholob@gmail.com

Анотація. Стаття присвячена бенчмаркінгу, щчо являє собою ефективний методуправління підприємством иляхом запровадження досвіду найбільш успішних компаній. В межах иієї роботи було обтрунтовано доиільність застосування бенчмаркінгу як антикризової стратегії підприємства.

Ключові слова: бенчмаркінг, стратегія, підприємство, криза.

Постановка проблеми. Успіх кожного підприємства залежить від багатьох чинників. Одним із найважливіших факторів $\epsilon$ ефективне управління суб'єктомгосподарювання. В свою чергу, основоположні принципи менеджменту підприємством чітко окреслені його ж стратегією. Досить часто для подолання багатьох проблем бізнесу (відставання від конкурентів, зменшення обсягів збуту, зниження рентабельності і т.д.) достатньо змінити існуючий спосіб керівництва, саме тому використання досвіду інших компаній (що і передбачає бенчмар-
Анотация. Статья посвящена бенчмаркингу, что представляет собой эффективный метод управления предприятия путем внедрения опыта наиболее успешных компаний. В рамках этой работы была обоснована иелесообразность применения бенчмаркинга как антикризисной стратеги предприятия.

Ключевые слова: бенчмаркинг, стратегия, предприятие, кризис.

кінг) набуває все більшої популярності, в тому числі й у вітчизняному економічному просторі. Таким чином, існує необхідність розглянути суть бенчмаркінгу, його переваги, недоліки та можливість адаптації в українських реаліях.

Аналіз останніх досліджень та публікацій. Зважаючи на те, що бенчмаркінг - поняття запозичене, перші дослідження у цій площині почали здійснювати західні вчені: Р. Кемп, Ф. Котлер, Б. Андерсен, О. Арєнкова. Розгляд цієї економічної категорії мав місце у працях таких українських науко- 
вців: Н. Афанасьєвої, Т. Лободзинської, Л. Тараєвської та інших.

Мета статті. Метою статті $є$ аналіз базових засад бечмаркінгу, оцінка можливостей застосування його як антикризового інструменту на вітчизняних підприємствах та розгляд основних переваг та недоліків даного процесу.

Виклад основних результатів. У сучасному світі інтелект людини та їі здібності $\epsilon$ основним засобом виробництва. В свою чергу саме це підштовхує на пошук та розробку нових управлінських технологій. Яскравим прикладом підходу, що забезпечує управління конкурентоспроможністю будь-якого успішного бізнесу є бенчмаркінг. По суті, бенчмаркінг - це унікальний інструмент, який дозволяє шляхом запровадження елементів досвіду найбільш успішних компаній не тільки підвищити конкурентоспроможність, а й уникати кризові явища. Бенчмаркінгові дослідження можуть демонструвати керівництву фірми не тільки де саме виникли проблеми, а й як швидко та відносно дешевше їх можна вирішити.

Батьківщиною такого явища як бенчмаркінг вважають Японію, оскільки довгий час там переважала підприємницька стратегія, за якої ідеально вивчалися європейські та американські товари та послуги, а саме визначалися сильні та слабкі сторони. Це дозволило японцям 3 урахуванням наявних недоліків фактично скопіювати готовий продукт, одночасно максимально вдосконаливши його. При чому, найбільшою перевагою для споживачів таких товарів та послуг стала ціна, оскільки таке копіювання передбачало менші обсяги витрат на розробку та виготовлення такого кінцевого продукту.

Звідси і бере початок сама назва бечмаркінгу, що за своїм змістом співвідноситься 3 японським словом «dantotsu», що означає «зусилля, занепокоєння, бажання (лідера) стати ще кращим (лідером)» [1].

У науковій економічній літературі зустрічаються різноманітні погляди щодо сутності поняття «бенчмаркінг». Наприклад, Роберт Кемп визначає зміст бенчмаркінгу як пошук найоптимальніших методів, що призводять до поліпшення діяльності підприємства [2].

На думку Н. Афанасьєвої, бенчмаркінг являє собою засіб для вдосконалення діяльності суб'єкта господарювання та оптимізація практики кращої якості з використанням досвіду найкращого в цій сфері. Також науковець впевнена, що такий підхід є дієвим механізмом порівняльного аналізу ефективності роботи однієї компанії 3 показниками інших, більш успішних фірм [3].

Б. Аднерсен визначає бенчмаркінг як постійне вимірювання і порівняння окремого бізнес-процесу з еталонним процесом провідної організації для збору інформації, яке допоможе підприємству визначити мету свого удосконалювання й проведення заходів щодо поліпшення роботи[4].

Усі вищенаведені підходи свідчать про те, що бенчмаркінг дійсно може стати дієвим способом уникнення кризових явищ на підприємствах різних галузей.

Останнім часом бенчмаркінг стає досить поширеним явищем і набуває репутацію дієвого методу управління 
бізнесом у міжнародному економічному середовищі. Як свідчить українська реальність, бенчмаркінг не здобув ще високого рівня довіри, тому нерідко у вітчизняних бізнесменів асоціюється з промисловим шпигунством або розвідкою. Проте така позиція $\epsilon$ досить помилковою, оскільки весь світ сьогодні рухається шляхом вдосконалення вже існуючих проце- сів, саме тому важливо більш детально розглянути складові бенчмаркінгу та його роль.

В деякому сенсі бенчмаркінг як економічну категорію можна асоціювати 3 стратегією підприємства, оскільки навіть самі види бенчмаркінгу класифікуються за схожими ознаками (рис.1).

\section{Види бенчмаркінгу:}

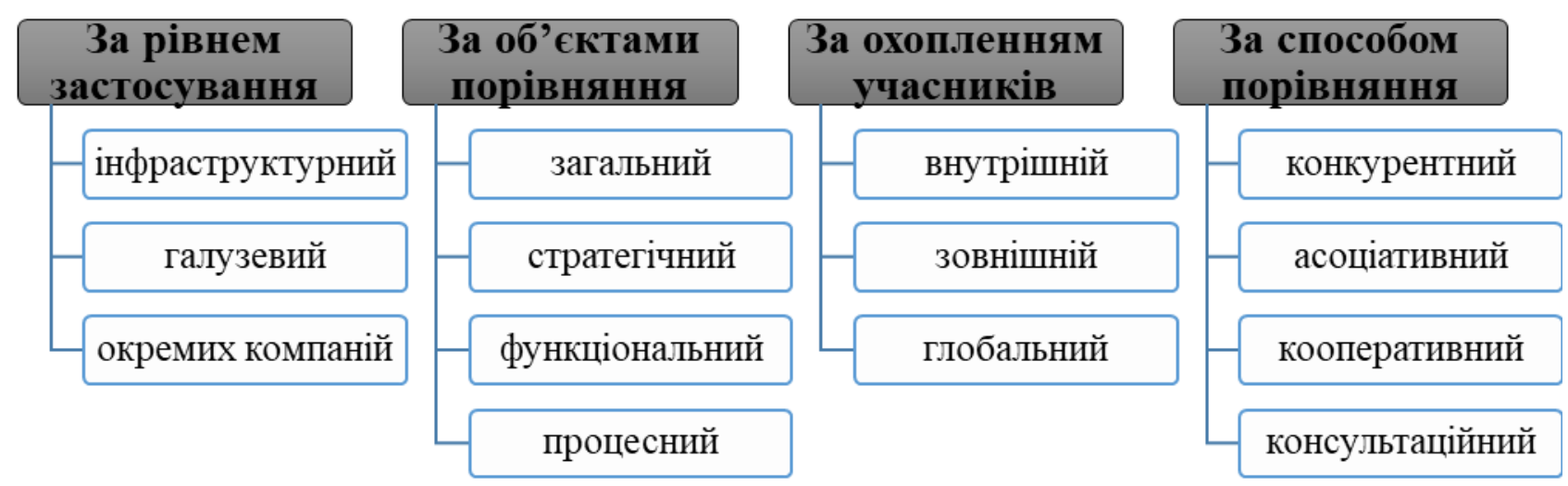

Рис. 1. Класифікація бенчмаркінгу Джерело:складено авторами на основі джерела [5]

За рівнем застосування розрізняють інфраструктурний, галузевий та бенчмаркінг окремих компаній. Інфраструктурний передбачає перенесення успішного досвіду від різних компаній і на різні компанії, тобто незалежно від їх сфери діяльності. В свою чергу, галузевий зумовлює певну спеціалізацію, тобто, за приклад береться компанія такого ж напрямку діяльності, що є дещо простішим процесом, зважаючи на аналогічність проблем, що можуть виникнути в галузі. Бенчмаркінг окремих компаній передбачає виконання шаблонних кроківпідприємства, яке було вибране у якості орієнтира.
За об'єктом порівняння можна виокремити загальний, стратегічний, функціональний та процес ний бенчмаркінг. Суть загального полягає в тому, що певна компаніє порівнюється за чітко обраними параметрами зі своїми непрямими конкурентами. Особливістю стратегічного $\epsilon$ те, що він розрахований на вивчення та впровадження успішних стратегій підприємствпартнерів. Під час функціонального бенчмаркінгу порівнюється спосіб виконання деяких функцій підприємств (збут, виробництво, маркетинг) і переймається досвід тієї компанії, яке $\epsilon$ лідером за відповідним функціональним напрямком. В свою чергу, процесний передбачає аналогію застосуван- 
ня конкретних прийомів, дій, характеристик процесу.

За охопленням учасників розрізняють внутрішній, зовнішній та глобальний бенчмаркінг. Внутрішній використовується, як правило, у великих компаніях, коли можна проаналізувати та порівняти між собою показники діяльності дочірніх фірм, відділень, підрозділів одного й того є суб'єкта господарювання. Зовнішній застосовується при порівнянні 3 фірмоюлідером у галузі. Глобальний передбачає глибоке вивчення культури підприємства-взірця, його місії, візії, політики, культури й, навіть, національних особливостей.

Спосіб застосування поділяє бенчмаркінг на наступні види: конкурентний, асоціативний, кооперативний та консультаційний.Конкурентний передбачає зіставлення 3 прямими конкурентами фірми, тоді як асоціативний - 3 тими компаніями, які викликають асоціацію 3 обраною. Коли здійснюється порівняльний аналіз основних виробничих функцій зметою їх оптимізації, то має місце кооперативний бенчмаркінг. Консультативнийпередбачаєвивчення, аналіз та співставлення організації з іншими за допомогоюконсультаційноїслужби. В свою чергу, консультаційна служба може функціонувати повністюнезалежно, шукаючи, збираючи та аналізуючиінформацію без зайвого використання людських ресурсів, тобто без відволікання людей з організації.

Досить часто кризові явища на підприємстві настають у той момент, коли, коли відбуваються певні зміни; тобто тоді, коли існуючій підприємницькій структурі вже важко адапту- ватися, видозмінитися відповідно до оновлених умов. Саме тоді вся система розбалансовується, що і призводить до початків нової системи [6].

Таким чином, на сучасному етапі розвитку економічних відносин під кризовими явищами розуміють як порушений (розбалансований) стан підприємства, що характеризується зниженням його стійкості внаслідок впливів як зовнішніх, так і внутрішніх чинників.

Для ліквідації таких процесів застосовують антикризове управління. Оскільки бенчмаркінг і є специфічним способом управління, його можна вважати дієвим антикризовим механізмом. Для цього доцільно розглянути етапи бенчмаркінгу (рис.2).

Оскільки головними завданнями антикризових заходів $є$ раннє діагностування й передбачення майбутньої кризи, адаптація підприємства до змін, поновлення балансу i забезпечення комфортних умов існування, то кожен 3 етапів проведення бенчмаркінгу у кінцевому результаті може це забезпечити.

Наприклад, етап планування передбачає пошук основної проблеми, тобто ідентифікацію предмета, стосовно якого i буде здійснюватися бенчмаркінг. Це дозволить чітко окреслити причини кризового стану та усунути ïx. Перший рівень також передбачає пошук партнера, тобто такої компанії, успішний досвід якої міг би стати доречним та корисним. Останнім нюансом на етапі планування $\epsilon$ пошук необхідної інформації та методів їі збоpy.

Аналіз здійснюється на основі попередньо отриманої інформації. Він 
передбачає порівняння фактичних та планових показників ефективності підприємства.На етапі впровадження (інтеграції) дуже важливо довести результати попередніх етапів до усіх працівників, на яких нова отримана інформація може суттєво вплинути. Це дозволить не тільки розробити нові цілі, а й одержати схвалення у разі потреби перегляду цілей у відношенні ефективності.

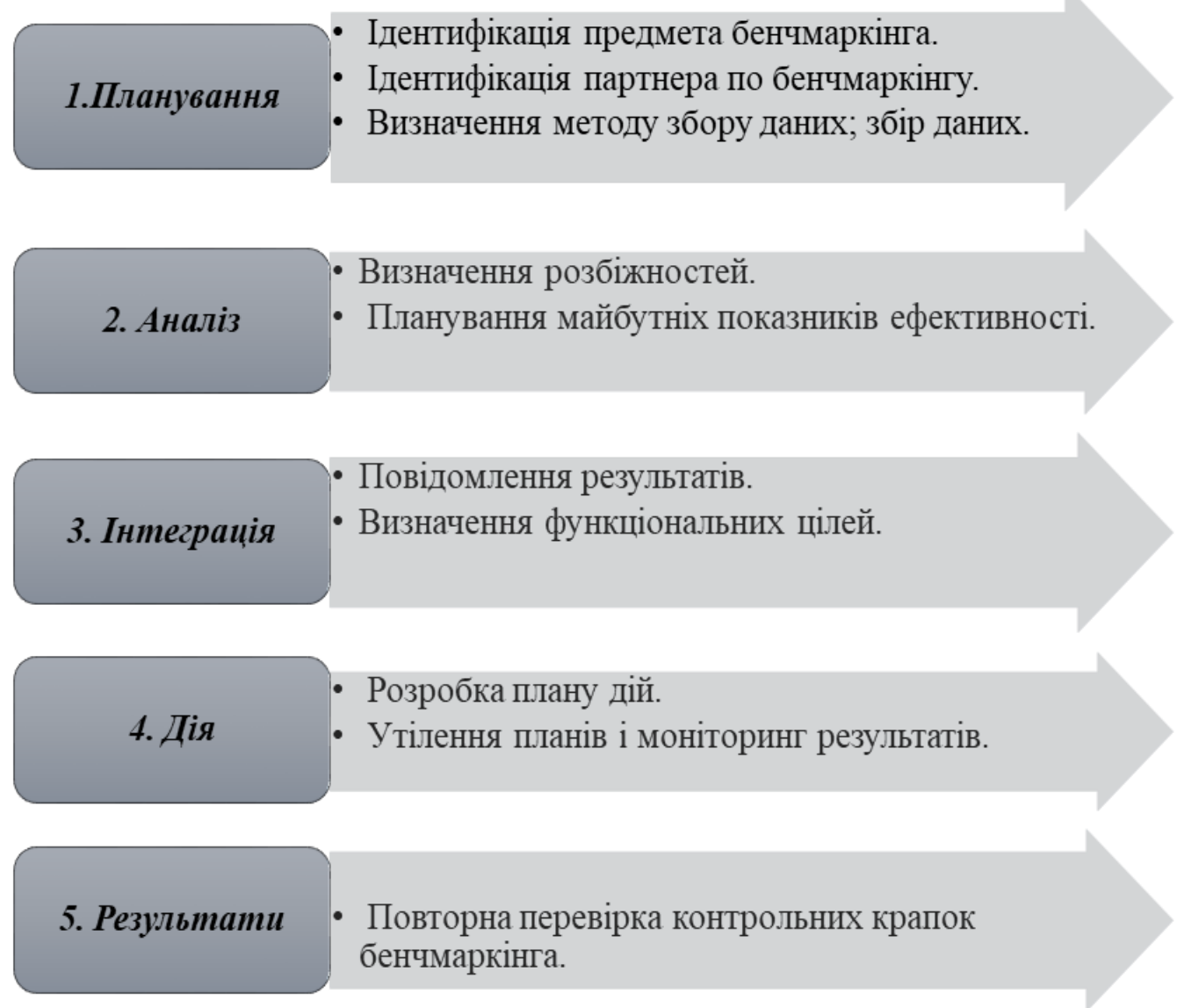

Рис. 2. Етапи проведення бенчмаркінгу

Джерело:складено авторами на основі джерела [2]

Четвертий етап означає дію. Він передбачає розробку конкретного покрокового стратегічного плану, його втілення та моніторинг отриманих результатів. На останньому етапі аналізуються отримані результати, внаслідок впровадження бенчмаркінгових заходів. Визначається, чи досягло підприємство очікуваних показників ефективності, чи стало воно лідером. Також здійснюється оцінка дієвості самого бенчмаркінгу як антикризової стратегіï.
Яскравим прикладом застосування бенчмаркінгових процесів є компанія Southwest Airlines- найбільша американська бюджетна авіакомпанія, яка займає 1-е місце за кількістю перевезених пасажирів, як в США, так і в світі. Як відомо, стратегія Southwest Airlines - низька вартість квитків, яка можлива за рахунок невеликої собівартості польотів. Досягається ж вона завдяки максимальному завантаженні парку літаків. 
Керівництво компанії передбачало можливість кризових явищ на підприємстві, й прагнучі уникнути їх, застосувало ефективну бенчмаркінгову програму. Перше, що було зроблено, це розрахунок часу наземного обслуговування (заправка літака, технічне обслуговування тощо). Після проведеного аналізу було прийнято рішення про скорочення часу перебування літаків на землі. Однак в порівнянні 3 іншими авіакомпаніями Southwest Airlines за цим показником були першими, тому пошук аналогів у своїй галузі здавався неможливим. Таким чином, було прийнято рішення звернутися до досвіду техніків, які обслуговують автогонки. На цьому етапі відбувся максимальний збір інформації, зокрема була вивчена спеціальна література, а також основні принципи роботи техніків «Формули1».Звичайно, на деякі процеси впливати було просто неможливо через існування регламентів 3 боку держави. Однак співробітники Southwest Airlines знайшли ті речі, на які вони мали можливість вплинути.

Наприклад, процеси пов'язані з розміщенням пасажирів, і в тому числі багажу [7].

Таким чином, в політику авіакомпанії в питання обслуговування літаків увійшли:

- жорсткий контроль кількості i розміру ручної поклажі (чим менше ручної поклажі, тим менше пасажири переміщаються по проходу, коли знімають свій багаж)

- очікування команди прибиральників біля трапу ще до звільнення салону;
- стандартні процедури роботи, хронометраж і методики (наприклад, попередньо зібрані набори);

- візуальний сигнал наземному персоналу, що подається членом екіпажу, коли літак готовий прийняти пасажирів;

- активне управліннярозміщенням багажу на полицях;

- доставка списку пасажирів агентом, що йде слідом за останнім пасажиром борту;

- очікування співробітника наземної служби біля трапу і його допомога в закриттілюку.

Звичайно, авіакомпанія не змогла довести час обслуговування літаків до показників «Формули-1», але це було і не потрібно. Досягнутого результату (скорочення часу обслуговування борту у 1,65 разів - 348 хвилин до 29) було досить для того, щоб збільшити кількість рейсів.

У свою чергу збільшення кількості рейсів дозволило авіакомпанії збільшити валовий прибуток, як наслідок чистий прибуток, примножити активи та акціонерний капітал підприємства протягом 2015-2018pp.

Відображення змін обсягу базових статей фінансової звідності Southwest Airlines динамічно зручніше прослідкувати на рис.3.

Крім того, про успішне застосування бенчмаркінгових процесів також свідчить поступовий, але впевнений ріст розмір у дивідендів по акціям Southwest Airlines (табл.1.). 


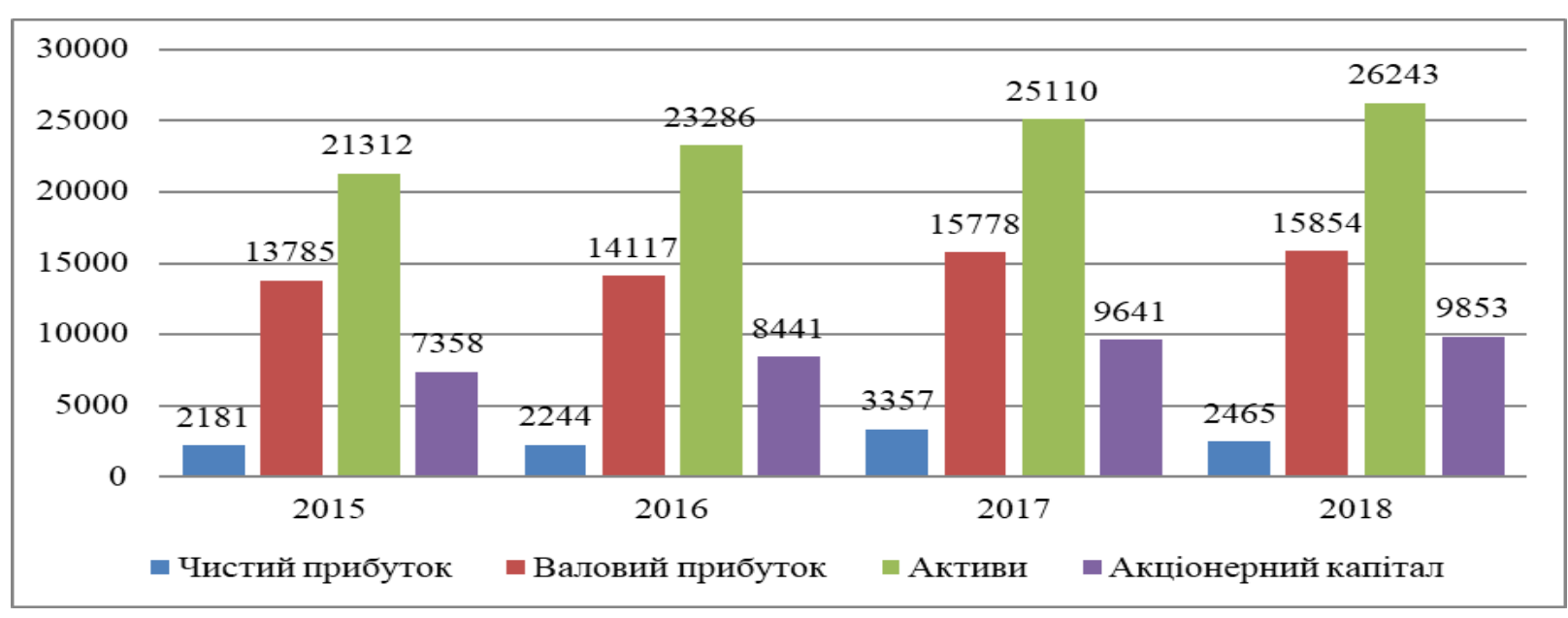

Рис.3. Базові статті звітності Southwest Airlines за 2015-2018 pp., млн. дол. США Джерело: складено авторами на основі джерела [7]

Таблиця 1

Ставки дивідендів по акціям Southwest Airlines протягом 2015-2018pp.

\begin{tabular}{|l|c|c|c|c|}
\hline & 2015 & 2016 & 2017 & 2018 \\
\hline Дивіденди по акціям & $0,78 \%$ & $0,76 \%$ & $0,84 \%$ & $1,15 \%$ \\
\hline
\end{tabular}

Джерело: складено авторами на основі джерела [7]

Беззаперечне зростання валового прибутку, активів підприємства, його акціонерного капіталу та дивідендів по акціям компанії свідчать про успішне використання бенчмаркінгу у якості антикризового та профілактичного заходу.

Як бачимо, бенчмаркінг як антикризова стратегія торкається усього: принципів функціонування процесів, технологій, якісних параметрів продукції, показників ефективності не тільки підприємства в цілому, а й навіть аналізу господарської діяльності структурних підрозділів. Така детальна діагностика і планування, засноване на результатах діяльності успішних компаній дійсно може стати ефективною антикризовою стратегією.

Загальновідомим є той факт, що наявність конкуренції, зміна умов функ- ціонування ринку вимагають від процесу управління підприємством максимальної ефективності та оптимізації, що неможливо без існування стратегічного планування, бюджетування, аналізу фінансово-економічних показників, контролю в усіх сферах діяльності підприємства, своєчасного антикризового фінансового управляння.Проте, сьогодення вимагає якісно нових, оригінальних, нестандартних підходів для подолання кризових явищ на підприємстві, саме це і передбачає бенчмаркінг. Так само, як і стратегічне антикризове управління бенчмаркінг охоплює наступі базові цілі: максимізація прибутковості; підвищення рівня збуту; зниження собівартості продукції та витрат загалом; охоплення більшого сегменту ринку; 
покращення якісної складової товарів та послуг тощо [8].

Застосування бенчмаркінгу може також слугувати своєрідним профілактичним заходом навіть до настання моменту кризи. Наприклад, він дозволяє своєчасно виявити недоліки у функціонуванні компанії, проаналізувати їх та вчасно запропонувати вже протестовані шляхи усунення.

До переваг також можна віднести можливість вивчати досвід діяльності компаній-лідерів, переосмислювати стратегічні орієнтири, переймати ідеї та досвід. Крім того, бенчмаркінг дає поштовх для розробок «ноу-хау» у певних галузях або навіть окремих процесах. Важливим $\epsilon$ те, що така стратегія дозволяє «триматися на плаву», а отже, завжди бути гідним конкурентом у своєму сегменті на рику. Бенчмаркінг не тільки передбачає вирішення кризових питань підприємства, а й планування діяльності суб'єкта господарювання за допомогою аналізу життєдіяльності конкурентів. Усе вищенаведене підкреслює доцільність застосування бенчмаркінгу якості ефективної антикризової стратегії [9].

Для вітчизняного ринкового середовища характерним є хаотичний, неорганізований обмін досвідом між компаніями. Так, наприклад, досить поширеною практикою $є$ те, що керівники підприємств обмінюються досвідом лише на професійних конференціях, семінарах за допомогою особистих знайомств або навіть у неформальній обстановці.

Крім того, існує ціла низка перешкод поширення бенчмаркінгу як ефективної управлінської стратегії, а саме:
- непрозорість економічного середовища;

- засекреченість компаній, закритий доступ до інформації;

- недостатньо розвинена інфраструктура бенчмаркінгу;

- відсутність своєрідних «клубів» для обміну досвідом;

- пасивність держави щодо фінансування бенчмаркінгових програм [10].

Досить часто керівники вітчизняних підприємств можуть відмовлятися від застосування бенчмаркінгу, аргументуючи це тим, що він передбачає значні витрати, які можуть бути не виправданими. До того ж, ділитися власними напрацюваннями - не $є$ рисою українського підприємця, а сам бенчмаркінг розцінюється як своєрідне шпигунство. Варто додати, що і самих фахівців 3 даного напрямку в Україні мало й підготовка фахівців у цій галузі майже не проводиться. Негативним $є$ i те, що досвід міжнародних компаній практично неможливо адаптувати до вітчизняних підприємств, оскільки економічні реалії різні.

Застосування бенчмаркінгу як антикризового механізму відкриває такі перспективні напрями розвитку, як:

- набуття вагомих конкурентних переваг для захоплення значної частки ринку та провідних позицій на ньому;

- отримання чіткого уявлення про власну позицію на ринку та майбутні перспективи;

- використання досвіду успішних практик для вдосконалення роботи власного підприємства 3 метою недопущення відставання від конкурентів і втрати власних позицій на ринку; 
- врахування потреб споживачів під час вибору шляхів розвитку;

-визначення й усунення недоліків, які перешкоджають розвитку підприємства;

- оновлення знань про власну галузь і конкурентів [11].

Крім того, ефективне застосування бенчмаркінгу на мікрорівні дасть поштовх для його існування на макрорівні, що також зможе допомогти подолати кризові явища не тільки на підприємствах, а й у економіці країни загалом.

Висновки. Таким чином, бенчмаркінг $є$ своєрідним мистецтвом виявляти і переймати те, що інші компанії роблять якісніше. Сам його процес проходить у п'ять основнихетапів: планування, аналізу, інтеграції, дії та результату. Правильне та своєчасне виконання вищенаведених кроків допоможе підприємству не тільки допомогти вийти 3 кризового стану, а й не потрапити в нього. Саме тому, бенчмаркінг можна вважати дієвим антикризовим механізмом. В принципі, його адаптація у вітчизняному просторі реальна, проте можуть виникнути деякі перешкоди: асоціювання бенчмаркінгу 3 промисловим шпіонажем; небажання успішних підприємств ділитися досвідом; нехватка кадрів зі знаннями у цій галузі. Проте, є й вагомі переваги бенчмаркінгу: набуття підприємством нових знань; чітке уявлення про власну позицію на ринку; своєчасне визначення проблем та їх усунення. Отже, бенчмаркінг дійсно може слугувати ефективним механізмом подолання кризових явищ на підприємстві.

\section{Список використаної літератури}

1. Аренков И.А., Багиев Е.Г. Бенчмаркинг и маркетингове решения. СПб: СПбГУ. 2001. 94 с.

2. Camp R. (1989). Benchmarking: the search for industry best practices that lead to superior performance. Milwaukee, WI: ASQ QualityPress. 299 p.

3. Афанасьева Н.В. , Багиев Г.Л. , Лейди Г. Концепция и инструментарий эффективного предпринимательства: учебноепособие. СПб.: СПбУЭФ. 1996.

4. Андерсен Б. Бизнес-процессы. Инструменты совершенствования/ пер. с англ. ; науч. ред. Ю. П. Адлер. М.: РИА «Стандарты и качество». 2003. 272 с.

5.Игнатовская Н.К. Бенчмаркинг в управлении фінансами компании. Актуальные проблемы авиации и космонавтики. 2016. №12. С. 950-952 6. Маховка В.М. Процес, методи та функції антикризового управління на підприємстві. Науковий вісник Полтавського університету економіки і торгівлі. 2012. № 1(52). С. 219-225. 
7. Фінансова звітність компанії Southwest Airlines: веб-сайт. URL: https://ru.investing.com/equities/sth-west-airlines-financial-summary (дата звернення: 11.11.2019).

8. Гордей О. Д., Довбуш Н.Є. Бюджетування як основа стратегічного планування на підприємствах малого і середнього бізнесу в Україні. Вісник ЖДТУ. 2019. № 1 (2018). c. 191-196. doi: https://doi.org/10.26642/jen-2019-1(87)-190-196.

9. Клименко С.М. Управління конкурентоспроможністю підприємства: Навчальний посібник. Київ : КНЕУ, 2006. 527 с.

10. Лютенко Д.Д., Хомич О.В., Лободзинська Т.Л. Проблеми та перспективи бенчмаркінгу на підприємствах України. Економіка і суспільство. 2017. № 13. C. 583-587.

11. Тіхонов Ю.В. Бенчмарікнг і бізнес-розвідка як складові успішного розвитку бізнесу. Актуальні проблеми економіки. 2007. №9 (75). с. 126-132. 